\title{
going for the centre of the world
}

\section{Moses Iten}

'He wants to go to the centre!' exclaims the man I’ve just asked for directions, winking to his friends. They are laying a cement foundation for a house, amongst wooden huts with dirt floors. An upgrade. They giggle and wave for me to continue along the only road. At each house - spaced fifty metres from each other - I keep asking for the same directions. 'El Centro?' a lady asks me at one of the many wooden kiosks that all seem to sell the same few things, 'bueno, just take a left at the next crossing.'

At the next crossing five boys are playing marbles on the gravel road. I stop to watch if they play by the same rules that I used to follow. But I can’t remember our rules. They ignore me, continuing in intense concentration, hopping about like little frogs to measure distances and retrieve strays. A group of men standing some distance away, though, watch me like I am watching the boys, while the boys watch their marbles. I look at the men watching me watch their boys. How could I be so curious about some boys playing marbles, when I was obviously the most curious thing in town? They are just boys with marbles. Not wanting to alarm anyone, I continue down the wide road. Going to the center, just to be going somewhere. Anywhere. Look for action. I could just stand still, lie in a hammock, read a book. But I don't.

I stop at an 'upgraded' market: tiled floors and half a dozen stores housed in a cement building. The seller can't change my fifty-peso note for some exotic soft drink with guarano, and goes from shop to shop in this empty market until he finds someone who can give him the change. There's some action. 
'There are people with vices, with ALCOHOL, with DRUGS, entering through Palenque, a city you should stay away from,' proclaims an evangelical voice in Castilian, blasted through megaphones. Tourists, like myself, also enter through Palenque. Some years ago from the opposite direction there were thousands of refugees fleeing massacre, but now mainly contraband enters from Guatemala. Just like any other border. I tune out as the megaphone discharges. The centre is crowded with dozens of men on bicycles, appearing to be listening, but more likely just talking amongst themselves. They are sitting on the back of their bikes, on the racks, looking like gangs of Harley drivers. They are farmers, some with baseball caps, others wearing more traditional or straw cowboy sombreros, all with rough hands, sinewy bodies and worn but friendly faces. I appear to be ignored, but catch frequent glances. I'm being observed.

The voice through the megaphones switches from Castilian to Chol and back, and I could understand it as it spoke of vice emanating from the city of Palenque. In Palenque - a tourist town and agricultural centre - I had left behind groups of European, Israeli and North American youths who spent days, weeks, months even - Who cares about time? Time is just time, you know? - on hammocks, with a joint in one hand and a Lonely Planet in the other, perhaps reading about 'this spread-out, edgy frontier town' in which I now find myself. 'Maaan, that sounds like a crazy place!' Back on the hammocks I had asked around if anyone was interested in coming along to the 'frontier'; several people expressed interest in crossing the frontier to the next hammock hang-out in Guatemala. But stay at the frontier?

At least I've found the centre, at last.

Sheltered inside the building to which the megaphones are fixed, women and children are listening to the evangelical youth sermon. Looking around in the dawn, I think I get the joke and giggle to myself: 'Ha! He wants to go to the centre!' Cruising amongst the crowds of Chol men milling about on bicycles, I spot two short, stocky, dark-skinned youths - one of them distinct in his tank-top and the other wearing a hooded jumper from northern Mexico - giggling in Castilian, crouching behind baskets of apples. An exotic fruit in this tropical outpost. I crouch down with them and it turns out they are 
from the Sierra of Puebla and Veracrúz. We embrace each other like paisanos, Indigenous compatriots from up north and a güero, me, who has adopted Veracrúz as home. Business has been slow, and these two have a whole truck of apples to sell in tropical Chiapas before heading home.

Accepted by these fellow foreigners, we giggle together about the absurdity of dozens of grown men on pushbikes, speaking to each other in hushed groups. Laugh about the heat, the pious sermon. Mourn the absence of any female inhabitants in the open spaces. Eat apples. Occasionally a man ambles over to buy one of the tiny but tasty apples, only showing polite interest, if any, in the jokes of the jolly guy from Veracrúz. In front of the local Choles, I feel boisterous, ignorant. But tolerated.

¿¿Qué se sembra en ... Australia?’ 'What do they grow in Australia? ... bueno ... everything,' I reply to the first question that follows my introduction to one of the groups of campesinos mounted on steeds of metal. 'It depends where you live; in the tropical north they grow bananas, cane, everything you'd expect in the tropics. Further south we have apples, wheat, and everything that grows in more temperate climates,' I stand there explaining to a growing audience. The sermon has turned towards me, so quickly have I become a preacher. It is bound to be better over there, hopes rise. The megaphones fade with the cackle of birds, gradually growing silent at dusk. Curious faces, but none the wiser, study me. We continue talking about the rural reality of Australia and Frontera Corozal, Chiapas. Don't know if you can call it talking, though, given their stunted Castilian and my gringo world of plenty that seems to represent all their dreams. All these men have either migrated here from the highlands, or been born to recent pioneers. Their Mayan forebears once lived in these regions, but the Spanish settlers carted them off from the unfamiliar tropics to tend to highland haciendas. Upon return, some may have found wealth (comparative to starvation) as they turned jungle into farms, but I expect most did not. With each mentioning of a price or salary their eyes grow wide, and fail to narrow again as I raise a negative point about the society I've come from. Or am I just justifying an economic wealth largely credited to a colonial and neo-colonial system put into place by so-called Westerners? Any philosophical points I could utter sound crude, as I translate them in my head and words melt before they pass my lips. I no longer feel boisterous, but gluttonous. 
It gets too dark to sell apples and people are leaving the centre. I walk back with the apple-seller from Veracrúz towards the hut in which my hammock is suspended. Around his neck hangs a fierce-looking canine tooth. 'It is from a boar,' he says, noticing my admiration. 'I swapped some apples for it, over in Guatemala.' You've been over there? 'Yes, yesterday I crossed the river with some apples. It wasn't worth my while, but you know, I couldn't be so close and not cross! I wanted to visit Guatemala.' He proudly shows me some copper and silver Quetzal coins, fingering them like pieces of gold, putting them back in his pocket. With a look of incredulity why had he sold good apples for mere lumps of decorative metal? - he advises me: 'These are no good here, but I want to keep them anyway, como recuerdo.' Recuerdo, a Castilian word connoting both 'memory,' and its physical manifestation, 'souvenir'. He mouths the word with a certain pride, like he can afford to be frivolous, make some memory tangible - even if there is no point in it. Before parting in the darkness, he confirms the price of a boat across the river. From there, he tells me about the existence of a once-a-day bus service into the interior of Guatemala. It leaves at 11am from the collection of huts I had spotted on the opposite side of the river.

Howler monkeys are roaring like fierce jaguars, somewhere in the uninhabited jungle towards Guatemala. Kids and their parents sit on the side of the road, watching one of the TVs that live on the counters of raw timber at every little kiosk here. They only sell expensive snack food. Presumably people here grow staples themselves, or barter. It is evident that most homes don't have a TV, or even access to electricity. They sit outside on the dirt, in front of those windows into other worlds. The few huts that do possess power are nonetheless exposed like sieves, light shining through the cracks between the thin boards making up the walls. The floors of the huts are dirt, and I can see hammocks through the doorways. After passing each TV my eyes have to readjust to the darkness and the silence of the night once again. 